\title{
Study on rules of dynamic variation of nitrogen in soil after reclaimed water drip irrigation
}

\author{
Jianhua Wang ${ }^{a}$, Shibao Lu ${ }^{b, *}$, Liang Pei ${ }^{c}$ \\ a State Key Laboratory of Simulation and Regulation of Water Cycles in River Basin, China Institute of Water \\ Resources and Hydropower Research, Beijing 100038, China \\ b School of Public Administration, Zhejiang University of Finance and Economics, Hang Zhou 310018, China \\ ${ }^{\mathrm{c}}$ Key Laboratory of Water Cycle and Related Land Surface Processes, Institute of Geographic Sciences and Natural \\ Resources Research, Chinese Academy of Sciences, Beijing 100101, China
}

\section{A R T I C L E I N F O}

Article history:

Received 30 March 2016

Accepted 3 May 2016

Available online 28 June 2016

\section{Keywords:}

Reclaimed water

Drip irrigation

Irrigated water quality

$\mathrm{NO}_{3}-\mathrm{N}$

$\mathrm{NH}_{4}^{+}-\mathrm{N}$

\begin{abstract}
A B S T R A C T
Reclaimed water belongs to one of makeup waters to be applied to agricultural production, which can not only reduce the quantity of wastewater effluent, but also reduce the quantity in demand of good-quality water, and is key element in utilization of limited water resources. Through field experimental method and taking drip irrigation, the regulation of reclaimed water drip irrigation on dynamic variation of nitrogen in soil was studied in this paper. The results indicate that compared to the contrast treatment, $\mathrm{NH}_{4}{ }^{+}-$ $\mathrm{N}$ content in the surface layer increased sharply in the initial period after reclaimed water drip irrigation, and then decreased significantly in the fifth day, and down to the level before irrigation on the ninth day, which was uniform between soil layers. $\mathrm{NO}_{3}-\mathrm{N}$ content under all the treatments presented the almost same trend in soil profile: $\mathrm{NO}_{3}-\mathrm{N}$ content increased with the soil depth, indicating an obvious tendency of $\mathrm{NO}_{3}-\mathrm{N}$ leaching down to lower layers. However, at the depth of $100-150 \mathrm{~cm}, \mathrm{NO}_{3}-\mathrm{N}$ content began to decrease. When reclaimed water drip irrigation was used for cucumber planting, $\mathrm{NO}_{3}-\mathrm{N}$ content in different layers at the ending of the growing period increased by $38.20 \%, 44.67 \%, 34.94 \%$, $30.88 \%$, respectively, than that before planting.
\end{abstract}

@ 2016 Published by Elsevier Ltd on behalf of Hydrogen Energy Publications LLC.

\section{Introduction}

Reclaimed water belongs to one of makeup waters to be applied to agricultural production, which can not only reduce the quantity of wastewater effluent, but also reduce the quantity demanded for good-quality water, and is key element in utilization of limited water resources with high efficiency. Yet, contaminating materials in the wastewater have not been fully removed as the result of economic and technical difficulties. The $\mathrm{N}$ and $\mathrm{P}$ element, higher salt content, various toxic trace substances and pathogenic agent abounded in reclaimed water possibly become new pollution source which could bring about adverse impact to the quality of soil and crop [1,2].

Reclaimed water belongs to the water resource which is reclaimed from non-conventional water resources such as the effluent discharged from sewage disposal plant, industrial water drainage and domestic wastewater that could be recycled for specific utilization due to acceptable water quality

\footnotetext{
* Corresponding author.

E-mail address: lu5111284@aliyun.com (S. Lu). 
after proper treatment [3-6]. Yet, the worldwide scarcity of water resources pushes on reuse of wastewater. It's estimated that water scarcity in China would reach $1.3 \times 10^{10} \mathrm{~m}^{3}$ and the quantity in demand of reclaimed water would reach $7.67 \times 10^{10} \mathrm{~m}^{3}$ in 2030. However, such countries as US, Australia, Israel, Japan and France etc. have already adopted reclaimed water as one of important solutions to alleviate the crisis of water resources. Furthermore, gross amount in demand of reclaimed water in Israel, Australia and Tunis etc. has respectively reached $25 \%, 11 \%$ and $10 \%$ total demand of water resources. Whereas reclaimed water is mainly applied to farming irrigation, the Werdbee Farm in Australia began to apply reclaimed water to irrigation since 1897, and $42 \%$ reclaimed water has already been applied to farming irrigation in US, but the irrigation by reclaimed water now is at starting point in China, e.g. Beijing Municipality plans to establish $40,000 \mathrm{hm}^{2}$ reclaimed water irrigated area and utilize $3 \times 10^{8} \mathrm{~m}^{3}$ reclaimed water in 2010. Along with the increase of reclaimed water irrigation area for 30 years, the safety and environmental impact of which has attracted wide attention [7-13]. The trend of irrigation by reclaimed water is spread worldwide and such countries as US, Australia, India, Israel and former USSR etc. have abounded in successful experience in utilization of poor quality water. But for long time, research fellows have only been focusing on the study of water salinity of irrigation water quality instead of in-depth and systematic study of chemical composition of irrigation water and its impact against physicochemical property of soil. Therefore, many countries recently began to focus on the study of impact from reclaimed water irrigation against soil physicochemical property and reclaimed water utilization approach [14-17].

On the one hand, reclaimed water irrigation can reduce serious non-point source pollution resulted from direct irrigation by wastewater, provide important nutrient to plant growth, promote plant growth and enhance crop yield [18-21]; on the other hand, superfluous nutrients, toxic chemicals and pathogenic agents will simultaneously enter environmental ecosystem along with the irrigation by reclaimed water, which would result in environmental pollution [22,23] and probably imperil human health. Moreover, the nitrogen also is one of key factors [23-25] in water body pollution and eutrophication even though it's one of important elements to make up biomass. Meanwhile, through excessive application of nitrogenous fertilizer and such human activities as unrestricted discharge of domestic sewage etc., massive nitrogen remains in soil after rejection by the crop and which would bring about latent and real environmental pollution [26-28] through volatilization, sprinkling or runoff etc. with composition pattern of $\mathrm{NO}_{3}{ }^{-}-\mathrm{N}$ and $\mathrm{NH}_{4}{ }^{+}-\mathrm{N}$. Therefore, the study of nitrogen in soil, especially the dynamic variation of $\mathrm{NO}_{3}{ }^{-}-\mathrm{N}$ and $\mathrm{NH}_{4}{ }^{+}-\mathrm{N}$ provides important theory and instruction to prediction and control of agricultural non-point source pollution.

Besides, with such characteristics as keeping watering duration, watering amount and soil moisture range in high control, drip irrigation can adjust soil moisture and nutrient according to soil physical property [29-33], distribution of crop root system and consumptive use of crop, and ensure crop yield with good quality and high yield while reducing agricultural non-point source pollution. The reuse of rural domestic sewage through drip irrigation will enhance utilization efficiency of such nutrients as nitrogen and phosphorus etc. in reclaimed water, which saves fertilizer, water and increases crop yield while reducing redundant pollutant entering environmental ecosystem, meanwhile it's significant in relief of water resources crisis [34-36], prevention and treatment of agricultural non-point pollution as well as promotion of recycling economy. Under similar conditions, this experiment compares and researches the rules of dynamic variations of nitrogenous agent in soil after drip irrigations by reclaimed water and groundwater with different proportion.

\section{Material \& method}

\section{Overview of experimental field}

The experimental field is entitled "Pilot Zone of Agricultural Non-point Source Pollution Control in Water Source Area at Centerline of South-to-North Diversion Project", which is jointly established by Geographical Science \& Resources Research Institute to Chinese Academy of Sciences and Policy \& Engineering Research Center to South-to-North Diversion Project to State Council. The experimental field is located in mountainous area at south part of Maojian District, Shiyan City, Hubei Province, where belongs to subtropical monsoon climatic region with 4 distinctive seasons and enjoys such characteristics as longer wintertime and shorter summertime, faster temperature rise during springtime, continuous precipitation during autumn days, less sleet during wintertime, relatively higher temperature during wintertime with less bitter cold, annual solar radiation of $106.6 \mathrm{kcal} / \mathrm{cm}^{2}$, physical radiation of $50.4 \mathrm{kcal} / \mathrm{cm}^{2}$, annual average sunshine duration of $1925.8 \mathrm{~h}$, mean annual temperature at $15.3^{\circ} \mathrm{C}$, extreme minimum temperature at $-14.9{ }^{\circ} \mathrm{C}$, extreme maximum temperature at $41^{\circ} \mathrm{C}, \geq 10^{\circ} \mathrm{C}$ annually accumulated temperature of $4936.5{ }^{\circ} \mathrm{C}$, annual frost-free period for 246 days, mean annual precipitation of $855 \mathrm{~mm}$, great fluctuation in annual rainfall, rainfall during flood period (from May 1st to October 20th) accounted for 58\%-62\% annual rainfall, which is endowed with great intensity, short duration, limited infiltration and liability to scour and erode ground surface. In addition, the soil in experimental field belongs to yellow-brown soil with unit weight between 1.56 and $1.71 \mathrm{~g} / \mathrm{cm}^{3}$.

\section{Tentative layout}

The experiment was conducted during growing period of cucumber in 2011 from September 20th to December 10th. Ridge planting is applied to the cucumber cultivation with $60 \mathrm{~cm}$-wide ridge shoulder, $15 \mathrm{~cm}$-high ridge height, $140 \mathrm{~cm}$ spacing between centerlines of two ridges, 2-row planting in the ridge and $40 \mathrm{~cm}$-wide plant spacing. Diammonium phosphate compound fertilizer is applied to the field with proportion of $20 \mathrm{~kg} / \mathrm{mu}$ before cucumber planting, and composition of irrigated water is classified with 3 marks as T1 (fully irrigated by reclaimed water), T2 (irrigation by water combined with $50 \%$ reclaimed water and $50 \%$ groundwater) and C (fully irrigated by groundwater), which is detailed in Table 1 below. The 3-classification experiment shall be 
Table 1 - Experimental drip irrigation by reclaimed water.

\begin{tabular}{ll} 
Mark & Composition of irrigated water \\
\hline T1 & Reclaimed water \\
T2 & $50 \%$ reclaimed water in total \\
& amount \\
C & Groundwater \\
\hline
\end{tabular}

conducted in 3 experimental plots, and every experimental plot enjoys $4 \mathrm{~m} \times 4 \mathrm{~m}$ area and includes 3 ridges with $4 \mathrm{~m}$ long length. The gravity drip irrigation shall be applied to the experiment with one drip irrigation hose embedded along centerline of every ridge, $20 \mathrm{~cm}$ dripper spacing equal to plant spacing, dripper discharge of $2.7 \mathrm{~L} / \mathrm{h}$, i.e. One dripper for one cucumber root. Each 3-category experiment (including 3 experimental plots) shall be equipped with 1 water tank (volumetric capacity of $240 \mathrm{~L}$ ) which is positioned some $1.2 \mathrm{~m}$ away from the ground for water supply. In the second experimental plot, one set of negative pressure gauge shall be embedded $20 \mathrm{~cm}$ deep beneath the dripper, when the gauge indicates that soil water potential is lower than $-25 \mathrm{kPa}$, drip irrigation shall be initiated with the amount of $5 \mathrm{~mm} /$ time and totally 7 times with gross amount of $35 \mathrm{~mm}$ during growing period of cucumber.

Besides, reclaimed water to be applied to this experiment is rural domestic wastewater filtrated through multi-layer soil percolation system $[7,37,38]$, and water quality of groundwater, domestic wastewater and reclaimed water is shown in Table 2, with which it can be seen that treatment effect of domestic wastewater through the simple multi-layer soil percolation system is not as good as expected, there are many indicators of reclaimed water still slightly exceeding national standard values.

\section{Measurement \& method}

The test shall be conducted during a watering duration within the cucumber growing period. Whereas drip irrigation for cucumber planting initiates on October 7th, it's required to carry out soil sampling in the second day, 5 th day and 9 th day after the irrigation with sampling depth $0-10 \mathrm{~cm}, 10-20 \mathrm{~cm}, 20-40 \mathrm{~cm}$, $40-60 \mathrm{~cm}, 60-90 \mathrm{~cm}$ and $90-100 \mathrm{~cm} .1 \mathrm{~mol} / \mathrm{L} \mathrm{KCl}$ lixiviation process - flow analyzer shall be applied to the measurement of soil $\mathrm{NO}_{3}^{-} \mathrm{N}$, and $2 \% \mathrm{~K}_{2} \mathrm{SO}_{4}$ lixiviation process - flow analyzer shall be applied to the measurement of soil $\mathrm{NH}_{4}{ }^{+}-\mathrm{N}$.

\section{Analysis of results}

Dynamic variation of ammonium nitrogen in soil after drip irrigation with reclaimed water

Fig. 1 indicates dynamic variation of $\mathrm{NH}_{4}{ }^{+}-\mathrm{N}$ content in soil within a watering duration through different treatments. It can be seen from the Figure that the variation of $\mathrm{NH}_{4}{ }^{+}-\mathrm{N}$ in soil is mainly influenced by drip irrigation. The content of $\mathrm{NH}_{4}{ }^{+}-\mathrm{N}$ in topsoil has been keeping in relatively high level 3 days before drip irrigation, but the content of $\mathrm{NH}_{4}^{+}-\mathrm{N}$ in soil began to increase after drip irrigation $\mathrm{T} 1$ and $\mathrm{T} 2$, and which remarkably lowered 5 days after drip irrigation, and even lowered to the level before watering on 9th day after drip irrigation, showing uniform distribution in all soil layers. Due to extremely low content of $\mathrm{NH}_{4}{ }^{+}-\mathrm{N}$ in groundwater, the content of $\mathrm{NH}_{4}{ }^{+}-\mathrm{N}$ in soil profile varies little after drip irrigation with groundwater, and topsoil only shows a small amount of accumulation of $\mathrm{NH}_{4}^{+}-\mathrm{N}$ content, the major cause probably is that the increase of soil water content varies mineralization rate of nitrogen in soil and nitrification rate of $\mathrm{NH}_{4}{ }^{+}-\mathrm{N}$ in soil, i.e. relatively great soil moisture provides favorable condition to mineralization of nitrogen in soil while inhibiting nitrification of $\mathrm{NH}_{4}^{+}-\mathrm{N}$ after drip irrigation, and short-time accumulation of $\mathrm{NH}_{4}{ }^{+}-\mathrm{N}$ takes place due to that mineralization rate probably is obviously faster than nitrification rate of $\mathrm{NH}_{4}{ }^{+}-\mathrm{N}$ in the meantime.

\section{Dynamic variation of nitrate nitrogen in soil after drip irrigation with reclaimed water}

Fig. 2 indicates dynamic variation of $\mathrm{NO}_{3}^{-} \mathrm{N}$ content after drip irrigation with different treatments. It can be seen from the Figure that $\mathrm{NO}_{3}^{-} \mathrm{N}$ content shows consistent variation along soil profile, i.e. gradually increasing from topsoil down to bottom layer. On the second day after drip irrigation, the content of $\mathrm{NO}_{3}^{-} \mathrm{N}$ increases obviously in bottom layer of soil, but begins to decline since 5 th day after drip irrigation, and

Table 2 - Comparison between water quality index, measuring method \& national relevant standards.

\begin{tabular}{|c|c|c|c|c|c|}
\hline Item & Groundwater & $\begin{array}{c}\text { Domestic } \\
\text { wastewater }\end{array}$ & $\begin{array}{l}\text { Reclaimed } \\
\text { water }\end{array}$ & Analysis method & $\begin{array}{c}\text { Irrigation } \\
\text { water quality } \\
\text { standard } \\
\text { (GB5084-2005)-vegetable } \\
{[11]}\end{array}$ \\
\hline $\mathrm{COD}_{\mathrm{Cr}}\left(\mathrm{mg} \mathrm{L}^{-1}\right)$ & $3.21-5.83$ & $450-730$ & $68-112$ & Dichromate process & 100 \\
\hline $\mathrm{NH}_{3}-\mathrm{N}\left(\mathrm{mg} \mathrm{L}^{-}\right)$ & $0.08-0.17$ & $73-108$ & $14-29$ & Nessler's reagent colorimetric method & - \\
\hline Turbidity & $0.4-2$ & 20-113 & $21-98$ & Turbidity meter & - \\
\hline $\mathrm{SS}\left(\mathrm{mg} \mathrm{L}^{-1}\right)$ & $2-10$ & $60-190$ & $30-60$ & Gravimetric method & 60 \\
\hline Temperature & $10-20$ & $14-38$ & $14-38$ & Thermometer & - \\
\hline $\mathrm{pH}$ & $7-8$ & $6-9$ & $6-9$ & Glass electrode method & $6-9$ \\
\hline $\mathrm{BOD}_{5}\left(\mathrm{mg} \mathrm{L}^{-1}\right)$ & $1.2-2.33$ & $179-271$ & $28-47$ & Dilution inoculation method & 40 \\
\hline $\mathrm{DO}\left(\mathrm{mg} \mathrm{L}^{-1}\right)$ & $0.21-0.14$ & $2.9-5.7$ & $2.0-4.8$ & Portable dissolution measuring apparatus & $\geq 0.5$ \\
\hline $\mathrm{TN}\left(\mathrm{mg} \mathrm{L}^{-1}\right)$ & $0.99-2.03$ & $53-79$ & $17-37$ & Ultraviolet spectrophotometry & $\leq 30$ \\
\hline $\mathrm{TP}\left(\mathrm{mg} \mathrm{L}^{-1}\right)$ & $0.08-0.22$ & $4.9-10.4$ & $4.1-9.3$ & aluminic acid Spectrophotometric method & $\leq 30$ \\
\hline
\end{tabular}


Ammonium nitrogen $(\mathrm{mg} / \mathrm{kg}$ ) (Ammonium nitrogen $\mathrm{mg} / \mathrm{kg}$ ) Ammonium nitrogen $(\mathrm{mg} / \mathrm{kg}$ )

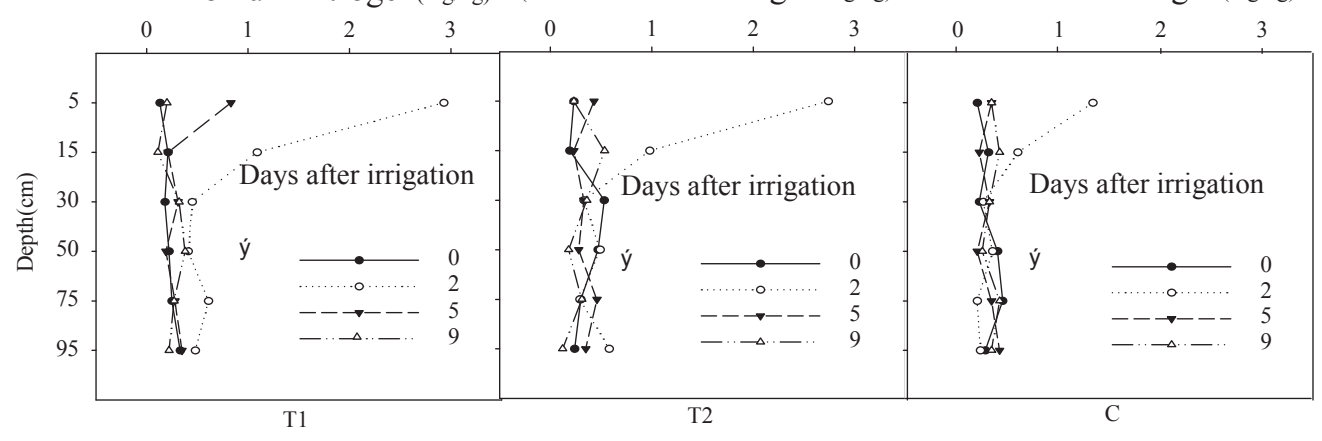

Fig. 1 - Variation of $\mathrm{NH}_{4}^{+}-\mathrm{N}$ content in soil after different treatments.

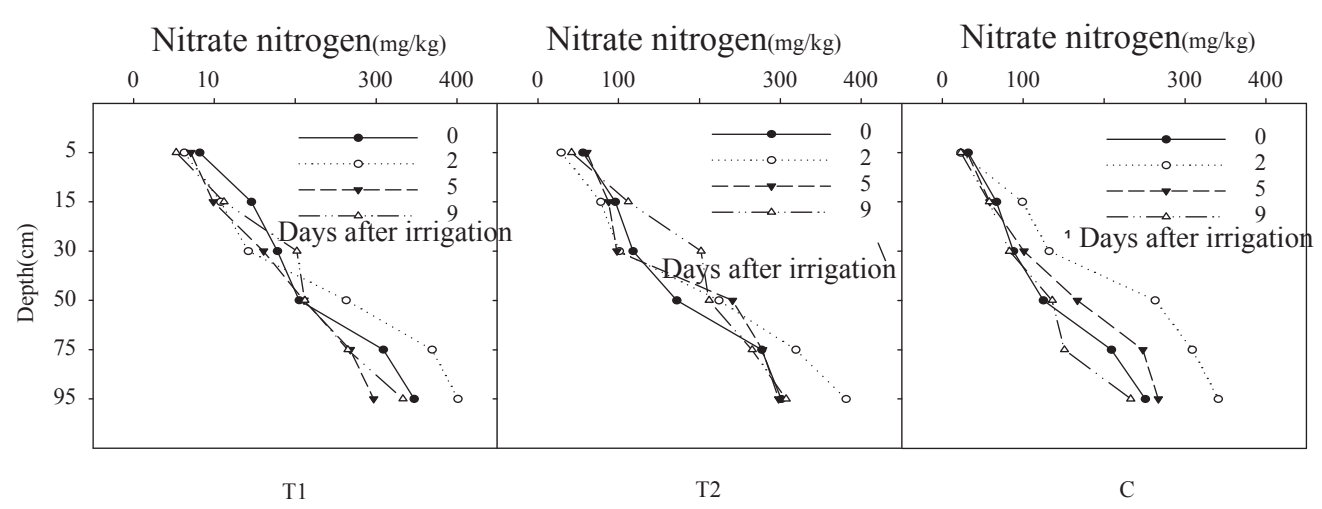

Fig. 2 - Variation of $\mathrm{NO}_{3}{ }^{-}-\mathrm{N}$ content in soil after different treatments.

nearly matches with the content of $\mathrm{NO}_{3}^{-} \mathrm{N}$ on 9th day after drip irrigation. Whereas the content of $\mathrm{NO}_{3}^{-} \mathrm{N}$ in soil begins to gradually rise along with the increase of depth, hence we select T1 approach and compare the variation of $\mathrm{NO}_{3}^{-} \mathrm{N}$ content in soil layer with depth between 0 and $200 \mathrm{~cm}$ before watering at the beginning of growing period and after watering at the end of growing period, this 2-process measurement is conducted once every $50 \mathrm{~cm}$ deep as shown in Fig. 3. It's measured out that the content of $\mathrm{NO}_{3}^{-} \mathrm{N}$ in soil increases $38.20 \%, 44.67 \%, 34.94 \%$ and $30.88 \%$ respectively at soil layers $(0-50 \mathrm{~cm}, 50-100 \mathrm{~cm}, 100-150 \mathrm{~cm}$ and $150-200 \mathrm{~cm})$ before watering. But which begins to decline at the depth of $1.5 \mathrm{~m}$.

\section{Conclusion}

The influence on soil dispersion rate and saturated hydraulic conductivity which is resulted from reclaimed water irrigation is correlated with the frequency of continuous irrigation with reclaimed water. This article concluded as follows:

The content of $\mathrm{NH}_{4}{ }^{+}-\mathrm{N}$ in topsoil sharply increases after drip irrigation with reclaimed water, but obviously declines on 5 th day after drip irrigation and lower to original level on 9th day after drip irrigation. The content of $\mathrm{NO}_{3}^{-} \mathrm{N}$ in soil after different treatments shows consistent variation, i.e. gradually increasing from topsoil down to bottom layer, which shows obvious process of downward spread of $\mathrm{NO}_{3}^{-} \mathrm{N}$ content. But $\mathrm{NO}_{3}^{-} \mathrm{N}$ content begins to decline at the depth between 100 and
$150 \mathrm{~cm}$, which indicates that the content of $\mathrm{NO}_{3}^{-} \mathrm{N}$ averagely increases $38.20 \%, 44.67 \%, 34.94 \%$ and $30.88 \%$ respectively at the depths $(0-50 \mathrm{~cm}, 50-100 \mathrm{~cm}, 100-150 \mathrm{~cm}$ and $150-200 \mathrm{~cm}$ ) when drip irrigation with reclaimed water is suspended at the end of cucumber growing period.

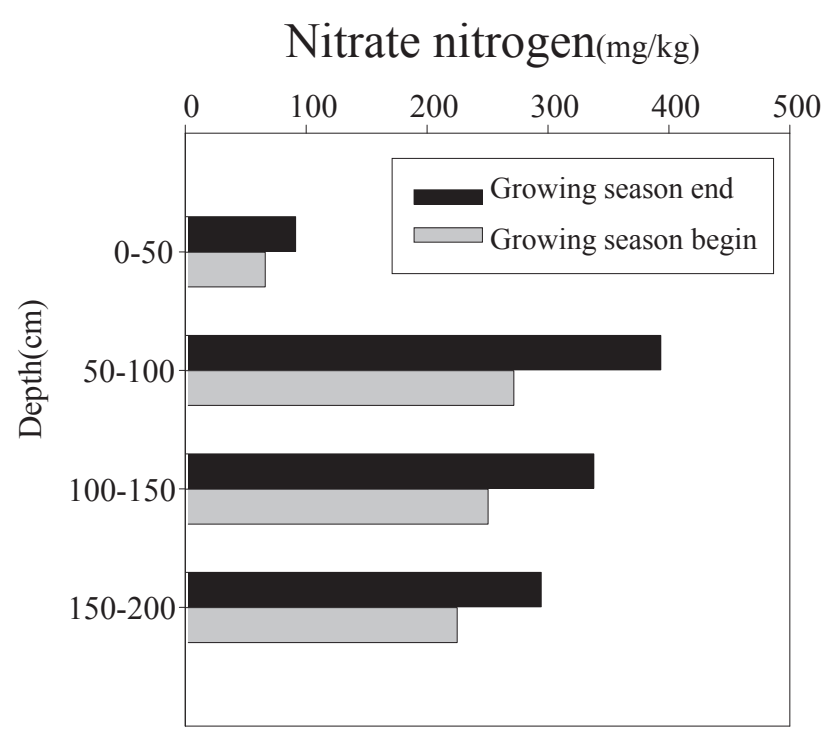

Fig. 3 - Variation of $\mathrm{NO}_{3}{ }^{-}-\mathrm{N}$ content in different soil layers. 
Due to there is enrichment of pollutant in soil to a certain degree under the condition of drip irrigation with reclaimed water, there must be some contaminants entering groundwater system when contaminant concentration in reclaimed water reaches great degree [39,40], and which might bring about adverse impact to soil environment, plant growth and crop yield.

At present, ecological risk of new-type contaminant in utilization of irrigation with reclaimed water is attracting widespread attention from the research fellows. However, it's appropriate to enhance relevant scientific research and subsequently provide scientific references to risk control in spite of various categories, complexity in transformation of soil ecosystem, lack of relevant environmental standards and difficulty in effectively evaluating environment risk with existing data.

\section{Acknowledgment}

The paper is funded by the National Social Science Foundation of China (Grant No: 14BGL205).

\section{R E F E R E N C E S}

[1] Irénikatché Akponikpè PB, Wima Koff, Yacouba Hamma, Mermoud Andre. A reuse of domestic wastewater treated in macrophyte ponds to irrigate tomato and eggplant in semiarid West-Africa: benefits and risks. Agric Water Manag 2011;98:834-40.

[2] Jang Taeil, Lee Sae-Bom, Sung Choung-Hyun, Lee Han-Phil, Park Seung-Woo. Safe application of reclaimed water reuse for agriculture in Korea. Paddy Water Environ 2010;8:227-33.

[3] Jang TI, Kim HK, Seong CH, Lee EJ, Park SW. Assessing nutrient losses of reclaimed wastewater irrigation in paddy fields for sustainable agriculture. Agric Water Manag 2012;104:235-43.

[4] Joo JH, Lee SB. Effects of several Silicate fertilizer on Potatogrown field. J Agric Life Environ Sci 2011;23:29-33.

[5] Jung KW, Yoon CG, Jang JH, Jeon JH. Characteristics of indicator microorganisms in paddy rice plots after reclaimed water irrigation. Water Sci Technol 2007;55:267-73.

[6] Kang MS, Kim SM, Park SW, Lee JJ, Yoo KH. Assessment of reclaimed wastewater irrigation impacts on water quality, soil, and rice cultivation in paddy fields. J Environ Sci Health A 2007;42:439-45.

[7] Lu Shibao, Pei Liang, Bai Xiao. Study on method of domestic wastewater treatment through new-type multi-layer artificial wetland. Int J Hydrogen Energy 2015;40(34):11207-14.

[8] Pereira BFF, He ZL, Stoffella PJ, Melfi AJ. Reclaimed wastewater: effects on citrus nutrition. Agric Water Manag 2011;98:1828-33.

[9] Antonopoulos Vassilis Z. Modelling of water and nitrogen balances in the ponded water and soil profile of rice fields in Northern Greece. Agric Water Manag 2010;98:321-30.

[10] Xu J, Peng S, Yang S, Wang W. Ammonia volatilization losses from a rice paddy with different irrigation and nitrogen managements. Agric Water Manag 2012;104:184-92.
[11] Singh PK, Deshbhratar PB, Ramteke DS. Effects of sewage wastewater irrigation on soil properties, crop yield and environment. Agric Water Manag 2012;103:100-4.

[12] Lu S, Wang J, Pei L. Study on the effects of irrigation with reclaimed water on the content and distribution of heavy metals in soil. Int J Environ Res Public Health 2016;13:298.

[13] Abdelrahman AH, Al Yafie BA, Goosen MFA. Evaluation of environmental factors and equipment configuration on efficiency of a solar soil water collector. Int J Environ Technol Manag 2009;10:260-74.

[14] Ahmad K, Ejaz A, Azam M, Khan ZI, Ashraf M. Cadmium and chromium contents of canola irrigated with sewage water. Pak J Bot 2011;43:1403-10.

[15] Alade GA, Ojoawo SO. Purification of domestic sewage by water- hyacinth (Eichhornia crassipes). Int J Environ Technol Manag 2009;10:286-94.

[16] Carr G, Potter RB, Nortcliff S. Water reuse for irrigation in Jordan: perceptions of water quality among farmers. Agric Water Manag 2011;98:847-54.

[17] Da Fonseca AF, Melfia AJ, Montes CR. Maize growth and changes in soil fertility after irrigation with treated sewage effluent. II. Soil acidity, exchangeable cations, and sulfur, boron, and heavy metals availability. Commun Soil Sci Plant Anal 2005;36:1983-2003.

[18] Evanylo G, Ervin E, Zhang X. Reclaimed water for turfgrass irrigation. Water 2010;2:685-701.

[19] Galavi M, Jalali A, Ramroodi M, Mousavi SR, Galavi H. Effects of treated municipal wastewater on soil chemical properties and heavy metal uptake by sorghum (Sorghum Bicolor L.). J Agric Sci 2010;2:235-41.

[20] Carli C, Yuldashev F, Khalikov D, Condori B, Mares V, Monneveux P. Effect of different irrigation regimes on yield, water use efficiency and quality of potato (Solanum tuberosum L.) in the lowlands of Tashkent, Uzbekistan: a field and modeling perspective. Field Crops Res 2014:163:90-9.

[21] Subash N, Ram Mohan HS. Evaluation of the impact of climatic trends and variability in rice-wheat system productivity using Cropping System Model DSSAT over the Indo-Gangetic Plains of India. Agric For Meteorol 2012;164:71-81.

[22] Bdour Ahmed N, Hamdi Moshrik R, Tarawneh Zeyad. Perspectives on sustainable wastewater treatment technologies and reuse options in the urban areas of the Mediterranean region. Desalination 2009;237:162-74.

[23] Wang Jun, Wang Dejian. Nitrogen and phosphorus leaching losses from intensively managed paddy fields with straw retention. Agric Water Manag 2014;141:66-73.

[24] Wu C, Spongberg AL, Witter JD, Fang M, Czajkowski KP. Uptake of pharmaceutical and personal care products by soybean plants from soils applied with biosolids and irrigated with contaminated water. Environ Sci Technol 2010;44:6157-61.

[25] Deblonde T, Cossu-Leguille C, Hartemann P. Emerging pollutants in wastewater: a review of the literature. Int J Hyg Environ Health 2011;214:442-8.

[26] Kim SD, Cho J, Kim IS, Vanderford BJ, Snyder SA. Occurrence and removal of pharmaceuticals and endocrine disruptors in South Korean surface, drinking, and waste waters. Water Res 2007;41:1013-21.

[27] Sui Q Huang J, Deng SB, Yu G, Fan Q. Occurrence and removal of pharmaceuticals, caffeine and DEET in wastewater treatment plants of Beijing, China. Water Res 2010;44:417-26.

[28] Pisarenko AN, Stanford BD, Yan D, Gerrity D, Snyder SA. Effects of ozone and ozone/peroxide on trace organic contaminants and NDMA in drinking water and water reuse applications. Water Res 2012;46:316-26. 
[29] Wang J, Gardinali P. Analysis of selected pharmaceuticals in fish and the fresh water bodies directly affected by reclaimed water using liquid chromatography-tandem mass spectrometry. Anal Bioanal Chem 2012;404:2711-20.

[30] Beverly SR. Bisphenol A: an endocrine disruptor with widespread exposure and multiple effects. J Steroid Biochem Mol Biol 2011;127:27-34.

[31] Aronson D, , et alHoward PH. Environmental release, environmental concentrations, and ecological risk of $\mathrm{N}, \mathrm{N}$ diethyl-m-toluamide (DEET). Integr Environ Assess Manage 2012;8:135-66.

[32] Kirwan Matthew L. Tidal wetland stability in the face of human impacts and sea-level rise. Nature 2013;504:53-60.

[33] Syvitski JP, Kettner J, Overeem I, Hutton WH, Hannon T, Brakenridge GR, et al. Sinking deltas due to human activities. Nat Geosci 2009;2:681-6.

[34] Törnqvist Torbjörn E, Wallace Davin J, Storms Joep EA, Wallinga Jakob, van Dam Remke L, Blaauw Martijn.
Mississippi Delta subsidence primarily caused by compaction of Holocene strata. Nat Geosci 2008;1:173-6.

[35] He Qiang. Economic development and coastal ecosystem change in China. Sci Rep 2014;8:189-201.

[36] Dai ZJ, Liu JT. A thirteen-year record of bathymetric changes in the North Passage, Changjiang (Yangtze) estuary. Geomorphology 2013;187:101-7.

[37] Zhou Chuncai. The environmental geochemistry of trace elements and naturally radionuclides in a coal gangue brickmaking plant. Sci Rep 2014;28:280-91.

[38] Williamson CE, et al. Lakes and reservoirs as sentinels, integrators, and regulators of climate change. Limnol Oceanogr 2009;54:2273-82.

[39] Smith SV, Renwick WH, Bartley JD, Buddemeier RW. Distribution and significance of small, artificial water bodies across the United States landscape. Sci Total Environ 2002;299:21-36.

[40] Nilsson C, Reidy CA, Dynesius M, Revenga C. Fragmentation and flow regulation of the world's large river systems. Science 2005;308:405-8. 